\title{
Inheritance and Linkage Relationships of Allozyme Variants of Ilex paraguariensis St. Hil
}

\author{
Simone Neumann Wendt ${ }^{1,2^{*}}$, Valderês Aparecida de Sousa ${ }^{1}$, Alexandre Magno Sebbenn ${ }^{3}$, \\ José Alfredo Sturion ${ }^{1}$, Felipe Luíz ${ }^{1}$, Elisa Caroline da Silva Santos ${ }^{1}$ and Marguerite \\ Quoirin ${ }^{2}$ \\ ${ }^{I}$ Embrapa Florestas; C. P.: 319; 83411-000; Colombo - PR - Brasil. ${ }^{2}$ Universidade Federal do Paraná; C. P. \\ 19031; 81531-990; Curitiba - PR - Brasil. ${ }^{3}$ Instituto Florestal; C. P. 339; 13400-970; Piracicaba - SP - Brasil
}

\begin{abstract}
Eighteen enzyme systems were examined in Ilex paraguariensis St. Hil. using starch gel electrophoresis. Seven out of 12 active isozyme systems revealed one or more polymorphic loci (PGI, GOT, MR, G-6PDH, MDH, NDH, and 6$P G D H)$. However, the segregation and linkage analyses were performed only for PGI, GOT, G-6PDH and 6-PGDH systems. Gene segregation at these loci was regular, except for a few trees that showed segregation distortion. Weak linkage disequilibrium between loci was detected, but it was not enough to influence the multilocus estimate.
\end{abstract}

Key words: Erva-mate (matê), electrophoresis, loci, allele and segregation

\section{INTRODUCTION}

Biochemical marker allozymes are used in forest genetic studies since they constitute an excellent tool for breeding programs and genetic resources conservation (Bergmann and Hattemer, 1998; Finkeldey, 1998). They are mainly used in reproduction system studies, measures of population diversity and genetic structure, gene flow, migration inferences, studies of phylogeny and taxonomy and in the genomic mapping (Glaubitz and Moran, 2000). It is necessary to consider a specific gene marker to infer about inheritance mode and linkage equilibrium among loci (Gillet and Hattemer, 1989). Such studies are quite common for conifers, but they are rare for broad-leaved species (Sebbenn, 2004).
Ilex paraguariensis St. Hil. ("erva-mate") is a broad-leaved tree, native to South America (Oliveira and Rotta, 1985). It has several industrial applications, but is especially used for beverage preparation. Mate is a culture of important commercial value for South Brazil and neighbor countries, such as Paraguay and Argentina (Maccari Junior, 2000). Due to its strong and indiscriminate exploitation and intensive requirement, studies of its biology and genetics are necessary to guide conservation and improvement programs.

This work aimed to study the inheritance and linkage relationships of allozymes in $I$. paraguariensis, as part of a major study on the reproductive systems and genetic structure of this species.

*Author for correspondence: snwendt@ hotmail.com 


\section{MATERIAL AND METHODS}

\section{Plant material and samples}

The material was collected from a Seed Production Area located at Colombo - Parana State, Brazil (25 $20^{\prime} \mathrm{S}$ and $49^{\circ} 14^{\prime} \mathrm{W}$ and $920 \mathrm{~m}$ high). The seeds were submitted to stratification procedure for six months -. The seedling leaves from 25 mother trees and their respective progenies (30 progenies/mother tree) were analyzed.

\section{Electrophoresis}

The enzymes were extracted from $100 \mathrm{mg}$ of leaf tissues and crushed in liquid nitrogen. Subsequently, $240 \mu \mathrm{L}$ of extraction buffer (PVP-
$406 \%$, sucrose 5\%, $\mathrm{Na}_{2}$ EDTA. $2 \mathrm{H}_{2} \mathrm{O} 0.004$ mol.L ${ }^{1}$, DTT 0.026 mol. $\mathrm{L}^{-1}$, bovine serum albumin $1.5 \%$ and mercaptoethanol $1 \%$, dissolved in Tris- $\mathrm{HCl}$ 0.067 mol. $\mathrm{L}^{-1}$ buffer, $\mathrm{pH}$ 7.5) with $0.01 \mathrm{~g}$ of PVPP was added to leaf extracts. The wicks with enzymes from the mother tree and their respective progenies were positioned side by side in the gel. The protein separation was done by electrophoresis of horizontal starch gel containing $13 \%$ starch and $1.35 \%$ sucrose. Electrophoresis was conducted in three systems: Lithium-borate, Tris-citrate and Morpholine-citrate. The buffer composition and running conditions are shown in Table 1. Eighteen enzyme systems were examined (Table 2).

Table 1 - Buffers and running conditions for starch-gel electrophoresis of I. paraguariensis isozymes.

\begin{tabular}{|c|c|c|}
\hline Electrode buffer & Gel buffer & Running conditions \\
\hline $\begin{array}{l}\text { Lithium-borate-system } \\
0.191 \text { mol.L } L^{-1} \text { boric acid } \\
0.042 \text { mol. } \mathrm{L}^{-1} \text { lithium hydroxide } \\
\text { pH } 8.1\end{array}$ & $\begin{array}{l}13 \% \text { starch } \\
1.35 \% \text { sucrose } \\
0.051 \text { mol. } \mathrm{L}^{-1} \text { Tris } \\
0.009 \text { mol. } \mathrm{L}^{-1} \text { citric acid monohydrate } \\
\mathrm{pH} 8.1 \\
5 \%(\mathrm{v} / \mathrm{v}) \text { electrode buffer }\end{array}$ & $\begin{array}{l}75 \mathrm{~mA} \text { constant } \\
\text { for } 5 \mathrm{~h}\end{array}$ \\
\hline $\begin{array}{l}\text { Tris-citrate-system } \\
0.149 \text { mol. } \mathrm{L}^{-1} \quad \text { Tris } \\
0.043 \text { mol. } \mathrm{L}^{-1} \quad \text { citric acid monohydrate } \\
\text { pH } 7.5\end{array}$ & $\begin{array}{l}13 \% \text { starch } \\
1.35 \% \text { sucrose } \\
0.148 \text { mol.L } L^{-1} \text { Tris } \\
0.043 \text { mol.L } \mathrm{L}^{-1} \text { citric acid monohydrate } \\
\text { diluted } 1 \text { part buffer: } 3 \text { parts water } \\
\text { pH } 7.3\end{array}$ & $\begin{array}{l}150 \mathrm{~V} \text { constant } \\
\text { for } 51 / 2 \mathrm{~h}\end{array}$ \\
\hline $\begin{array}{l}\text { Morpholine-citrate-system } \\
0.040 \text { mol. } \mathrm{L}^{-1} \text { citric acid monohydrate } \\
\text { Adjust pH with } \mathrm{N} \text {-(aminopropyl) } \\
\text { pH } 6.1\end{array}$ & $\begin{array}{l}13 \% \text { starch } \\
1.35 \% \text { sucrose } \\
0.040 \text { mol. } \mathrm{L}^{-1} \text { citric acid monohydrate } \\
\text { Adjust pH with } \mathrm{N} \text {-(aminopropyl) } \\
\text { pH } 6.1\end{array}$ & $\begin{array}{l}65 \mathrm{~mA} \text { constant } \\
\text { for } 5 \mathrm{~h}\end{array}$ \\
\hline
\end{tabular}

Table 2 - Enzymes examined in this study, with their abbreviations and Enzyme Commission (E. C.) reference numbers.

\begin{tabular}{lcc}
\hline \multicolumn{1}{c}{ Enzyme systems } & Abbreviation & E. C. no. \\
\hline Aconitase & ACO & 4.2 .1 .3 \\
Alcohol dehydrogenase & ADH & 1.1 .1 .1 \\
Malic enzyme & ME & 1.1 .1 .40 \\
Acid phosphatase & ACP & 3.1 .3 .2 \\
Phosphoglucose isomerase & PGI & 5.3 .1 .9 \\
Phosphoglucomutase & PGM & 2.7 .5 .1 \\
6-Phosphogluconate dehydrogenase & 6-PGDH & 1.1 .1 .44 \\
Formiate dehydrogenase & FDH & 1.2 .1 .2 \\
Glutamate dehydrogenase & GDH & 1.4 .1 .3 \\
Glucose-6-phosphate dehydrogenase & G-6PDH & 1.1 .1 .49 \\
Glutamate oxaloacetate transaminase & GOT & 2.6 .1 .1 \\
Isocitrate dehydrogenase & IDH & 1.1 .1 .42 \\
Leucine aminopeptidase & LAP & 3.4 .11 .1 \\
Malate dehydrogenase & MDH & 1.1 .1 .37 \\
Menadion reductase & MR & 1.6 .99 .2 \\
NADH-dehydrogenase & NDH & 1.6 .99 .3 \\
Peroxidase & PO & 1.11 .1 .7 \\
Shikimic acid dehydrogenase & SKDH & 1.1 .1 .25 \\
\hline
\end{tabular}




\section{Segregation analysis}

The inheritance mode of $I$. paraguariensis was inferred according to Gillet and Hattemer (1989) method, which compared the mother tree with its open-pollinated progeny. The following conditions were checked and met using this method: a) all progeny of homozygous mother tree $\left(A_{i} A_{i}\right)$ possessed the allele of the maternal tree $\left(A_{i}\right)$; in case of heterozygous mother tree $\left(A_{i} A_{j}, i \neq j\right)$ : b) $\left(A_{i} A_{j}, \quad i \neq j\right): \quad$ b.1) each individual among the offsprings - contained one of the maternal alleles $A_{i}, A_{j}, \quad$ b.2) the number of the heterozygous progenies $A_{i} A_{j}\left(N_{i j}\right)$ was expected to be equal to the sum of homozygous progenies $A_{i} A_{i}\left(N_{i i}\right)$ and $A_{j} A_{j}$ $\left(N_{j j}\right), \quad N_{i j}=N_{i i}+N_{j j}$, b.3) the number of the heterozygous progenies $A_{i} A_{k}\left(N_{i k}\right)$ was expected to be equal to the number of the heterozygous progenies $A_{j} A_{k}\left(N_{j k}\right), N_{i k}=N_{j k}(k \neq i, j)$.

The homogeneity G test (Sokal and Rohlf, 1981), with one degree of freedom, was applied to compare the observed phenotypes in each progeny from heterozygous mother tree, with the expected $1: 1$ segregation hypothesis. Finally, all the individual tests were pooled and a $\mathrm{G}$ total test was obtained ( $\sum G_{\text {hypothesis: } 1}$ ) with $n$ degree of freedom, where $n$ represented the analyzed progenies. Simultaneously, the observed phenotypes were pooled and a $G$ test grouped for 1:1 segregation was obtained $\left(\sum G_{1: 1 \text { pooled }}\right)$ with one degree of freedom. The hypothesis of heterogeneity segregation between the progenies was tested throughout a $G$ test $\left(\sum G_{\text {hetergenenity }}\right)$, subtracting the pooled $G$ test $\left(\sum G_{1: 1 \text { pooled }}\right)$ from total $G$ test $\left(\sum G_{\text {hypothesis: } 1}\right)$. These statistics were additive, so that $\sum G_{\text {hypothesis: } 1}=\sum G_{\text {heterogeneity }}+\sum G_{1: 1 \text { pooled }}$, with $n$, $n-1$ and 1 degrees of freedom, respectively (Sousa et al., 2002). If the test was statistically significant, trees not conforming to the $1: 1$ segregation hypothesis were eliminated from the data and the statistical tests were repeated. Letters and numbers designated the loci and alleles identified in the gel, respectively, in the order of their migration rates towards the anode.

\section{Linkage analysis}

The linkage analysis was based on linkage disequilibria of Burrows, $\Delta_{i j}$ (Weir, 1979) and estimated by GDA software (Lewis and Zaykin, 1999). The chi-square $\left(\chi^{2}\right)$ tested the hypothesis of independent segregation (Weir, 1979).

\section{RESULTS AND DISCUSSION}

\section{Electrophoresis and enzyme polymorphism}

The extraction buffer was chosen after preliminary investigation.

The adjusted buffer efficiently preserved the activity of $I$. paraguariensis enzymes. Clear and reproducible zymograms were obtained for 12 enzymes: PGI, PGM, GOT and MR (Lithiumborate system - $\mathrm{pH}$ 8.1); ADH, GDH, G-6PDH, IDH, MDH, NDH, SKDH and 6-PGDH (Triscitrate system - $\mathrm{pH}$ 7.1). Poor resolution and unclear bands were observed for Morpholinecitrate system and for this reason, it was excluded from genetics analysis. The loci and alleles inferred from the zymograms and investigated in this study are listed in Table 3. A locus was considered polymorphic if the frequency of the most common allele was lower than $95 \%$. Seven from 12 active enzyme systems revealed one or more polymorphic loci.

\section{Description and segregation of isozyme banding patterns}

Monomorphic enzymes

Staining reactions for PGM, ADH, GDH, IDH and SKDH resulted in a single and uniform band. In the absence of variation, this band was empirically called locus $A$, with one allele (Table 3 ).

\section{Polymorphic enzymes}

Glutamate oxaloacetate transaminase (GOT)

Three polymorphic zones were identified in gels stained for GOT (Fig. 1). Each zone was controlled by two variants. The zones $\mathrm{B}$ and $\mathrm{C}$ revealed high polymorphism; however, they were excluded from the analysis because the bands were very weak and with overlapping zones and, therefore, the gel interpretation was difficult. Only GOT-A was used for genetic analysis. GOT revealed the typical pattern of dimeric enzymes, with heterozygous genotypes represented by three bands. 
Table 3 - Enzyme polymorphism observed in Seed Production Area of I. paraguariensis.

\begin{tabular}{lccl}
\hline Enzyme system & Loci Scored & Alleles Scored & Polymorphism \\
\hline Lithium-borate buffer $(p H$ 8.1) & & & \\
\hline PGI & A & 1 & no \\
& B & 4 & high \\
PGM & A & 1 & no \\
GOT & A & 2 & moderate \\
& B & 2 & high \\
MR & C & 2 & high \\
\hline Tris-citrate buffer $(\mathrm{pH} 7.5)$ & A & 2 & moderate \\
\hline ADH & & & \\
GDH & A & 1 & no \\
G-6 PDH & A & 1 & no \\
IDH & A & 2 & moderate \\
MDH & A & 1 & no \\
& A & 2 & moderate \\
NDH & B & 2 & high \\
& C & 1 & no \\
SKDH & A & 2 & low \\
6-PGDH & B & 1 & no \\
& A & 1 & no \\
\hline
\end{tabular}

\section{Phosphoglucose isomerase (PGI)}

Two PGI activity zones were observed and the most anodal was invariable, while the other showed four bands with high polymorphism. The phenotypes observed in B zone indicated that PGI was a dimeric enzyme (Fig. 1).In further analysis of natural populations, Wendt (2005) observed two variants in the fast migration zone and one more variant (the fifth one) in the second zone.

\section{Glucose-6-phosphate dehydrogenase (G-6PDH)} Gels stained for G-6PDH showed a single activity zone with two bands. The variants found in G$6 \mathrm{PDH}$ revealed a monomeric structure in $I$. paraguariensis (Fig. 1).

\section{Malate dehydrogenase (MDH)}

Three MDH activity zones were identified. Zones $\mathrm{A}$ and $\mathrm{B}$ were polymorphic showing two variants in each one. Zone $\mathrm{C}$ was monomorphic. A triplebanded variant when heterozygous suggested a dimeric structure for this enzyme. The patterns of zymograms were very complicated to understand. Therefore, this system was excluded from the data analysis. Konnert et al. (2001) also excluded MDH enzyme from their study with Acer pseudoplatanus as consequence of a complicated enzymatic pattern.

\section{Menadion reductase (MR)}

One zone with two variants appeared in gels stained for MR. This enzyme showed a tetrameric structure. However, it was not possible to identify all heterodimers. Therefore, this system was excluded from the genetic analysis. In most plant species, MR is a multimeric enzyme with a number of intragenic heterodimers in phenotypes of heterozygotes that makes their identification difficult (Finkeldey et al., 1998). Fallour et al., (1997) and Finkeldey et al., (1998) working with Pinus pinea and Pterocarpus indicus, respectively, also excluded the MR enzyme, as consequence of very complex banding patterns and difficulties in zymograms interpretation.

\section{NADH-dehydrogenase (NDH)}

Two enzyme activity zones were identified on gels stained for NDH. The faster migrating zone (A) stained weakly and showed two variants. These bands in the progenies were not clear enough to be evaluated. NDH revealed the typical pattern of monomeric enzyme. The B zone was monomorphic. However, studies in natural populations revealed polymorphism in the second zone (two variants) being utilized in the analyses of genetic structure (Wendt, 2005). 
6-Phosfogluconate dehydrogenase (6-PGDH) Two polymorphic zones were identified in gels stained for 6-PGDH. Each zone was controlled by two variants. The observed phenotypes showed that 6-PGDH isozyme in I. paraguariensis was a dimer (Fig. 1).

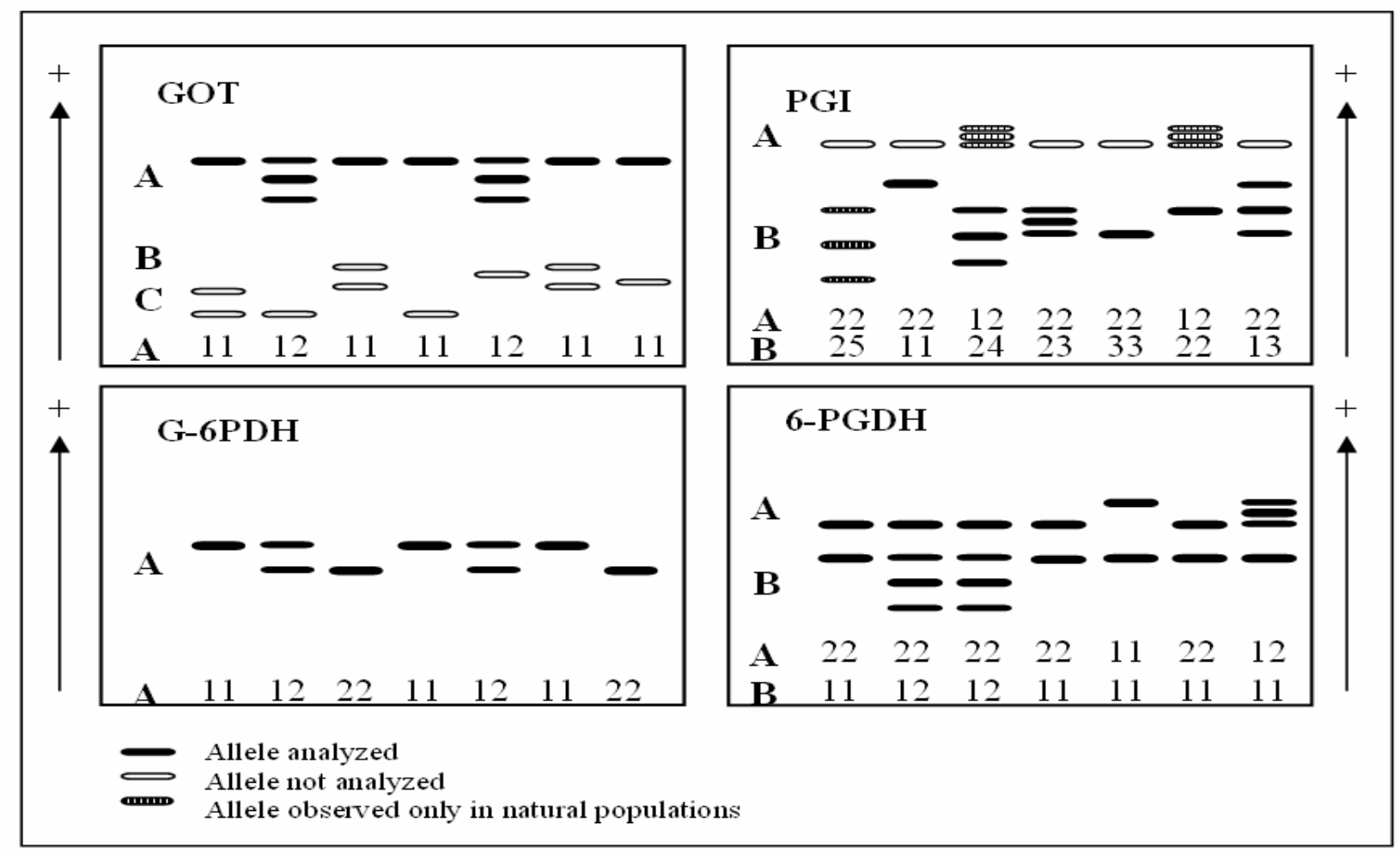

Figure 1 - Schematic diagram of enzyme phenotypes observed in I. paraguariensis.

\section{Segregation analysis}

Table 4 summarizes the tests of regular segregation ratios applied to enzyme bands to confirm the inferred genotypes.

GOT showed three activity zones; however, only GOT-A was utilized for segregation analysis, since the others were very complicated to analyze. The $G O T-A$ is controlled by one locus with two alleles. Although $A_{2}$ was not detected in homozygous form, the three analyzed trees did not show segregation deviation for both $G$ total $\left(\sum G_{\text {hypothesis:1: }}\right)$, heterogeneity $\left(\sum G_{\text {heterogeneity }}\right)$ and pooled segregation hypothesis 1:1 $\left(\sum G_{1: 1 \text { pooled }}\right)$. These results allowed considering that this zone was controlled by a codominant locus (Table 4).

The segregation analysis from $B_{1}$ and $B_{2}$ alleles in $P G I-B$ locus showed significant deviation segregation for all the tests performed. These results could be attributed to high deviations from C51 progeny.
When it was excluded from analysis, the data were perfectly adjusted (Table 4). Progenies from C51 tree showed an excess of heterozygote genotype $\left(N_{j k}\right)$ prevailing the $B_{2} B_{3}$ type (25 individuals) (Table 5). The natural selection might explain these results since those deleterious alleles could be eliminated favoring this type. Linkage between gene markers and deleterious alleles was described by Furnier et al. (1986) and Strauss and Conkle (1986) as a reason for segregation distortion. Recessive deleterious alleles linked with gene markers are normally frequent in tree species of crossed pollination (Willians and Savolainen, 1996).

The three heterozygous trees $B_{2} B_{3}$ at $P G I-B$ locus, showed regular segregation for both $B_{2}$ and $B_{3}$ alleles. The genotypes $B_{1} B_{3}, B_{1} B_{4}$ and $B_{2} B_{4}$ were observed for just one tree. The segregation for $B_{1}$ and $B_{3}$ alleles was according to expected ratio $\left(G_{1: 1 \text { pooled }}\right)$. 
Table 4 - Test for hypothesis of regular segregation $(G)$ of isozyme markers in I. paraguariensis.

\begin{tabular}{|c|c|c|c|c|c|c|c|c|c|c|c|c|}
\hline \multirow{2}{*}{$\begin{array}{r}\text { Locus } \\
G O T-A\end{array}$} & \multirow{2}{*}{$\begin{array}{c}\begin{array}{c}\text { Maternal } \\
\text { genotype }\end{array} \\
A_{l} A_{2}\end{array}$} & \multirow{2}{*}{$\begin{array}{c}\text { Case } \\
\mathrm{a}\end{array}$} & \multirow{2}{*}{$\begin{array}{c}\begin{array}{c}\text { Number } \\
\text { of trees }(n)\end{array} \\
3\end{array}$} & \multicolumn{2}{|c|}{$\sum N_{i j}: \sum\left(N_{i i}+N_{i j}\right) \sum N_{i k}: \sum N_{j k}$} & \multicolumn{2}{|c|}{$\begin{array}{c}\sum G_{\text {hypothesisl: } 1} \\
\mathbf{G L}=\boldsymbol{n}\end{array}$} & \multicolumn{2}{|c|}{$\begin{array}{c}\sum G_{\text {heterogenaty }} \\
\mathbf{G L}=\boldsymbol{n}-\mathbf{1}\end{array}$} & \multicolumn{2}{|c|}{$\begin{array}{c}\sum G_{1: 1 \text { pooled }} \\
\mathbf{G L}=\mathbf{1}\end{array}$} & \multirow{2}{*}{$\begin{array}{c}\text { Trees with } \\
\text { unbalanced } \\
\text { allele ratios }\end{array}$} \\
\hline & & & & $46: 43$ & - & 0.30 & & 0.20 & & 0.10 & & \\
\hline \multirow{6}{*}{$P G I-B$} & $B_{1} B_{2}$ & $\mathrm{a}$ & 10 & 106:133 & $14: 43$ & 56.12 & $* *$ & 37.81 & $* *$ & 18.31 & $* *$ & 1 \\
\hline & & b & 9 & 105:131 & $13: 18$ & 28.55 & & 24.87 & & 3.68 & & \\
\hline & $B_{1} B_{3}$ & $\mathrm{a}$ & 1 & $10: 9$ & $5: 6$ & - & & - & & 0.90 & & \\
\hline & $B_{1} B_{4}$ & $\mathrm{a}$ & 1 & $2: 3$ & $18: 7$ & - & & - & & 13.33 & $* *$ & 1 \\
\hline & $B_{2} B_{3}$ & $\mathrm{a}$ & 3 & $37: 40$ & $6: 7$ & 7.19 & & 7.07 & $*$ & 0.12 & & \\
\hline & $B_{2} B_{4}$ & a & 1 & $0: 12$ & 17:0 & - & & - & & 40.20 & $* *$ & 1 \\
\hline \multirow[t]{2}{*}{ 6-PGDH-A } & $A_{1} A_{2}$ & $\mathrm{a}$ & 11 & $79: 194$ & - & 77.92 & $* *$ & 27.93 & $* *$ & 49.99 & $* *$ & 8 \\
\hline & & $\mathrm{b}$ & 3 & $34: 40$ & - & 6.27 & & 5.79 & & 0.49 & & \\
\hline 6-PGDH-B & $B_{1} B_{2}$ & $\mathrm{a}$ & 1 & $16: 14$ & - & - & & - & & 0.13 & & \\
\hline \multirow[t]{2}{*}{$G-6 P D H-A$} & $A_{1} A_{2}$ & a & 11 & $111: 212$ & - & 42.39 & $* *$ & 10.28 & & 32.12 & $* *$ & 6 \\
\hline & & b & 5 & $63: 83$ & - & 3.27 & & 0.52 & & 2.75 & & \\
\hline
\end{tabular}

$N_{i j}$ and $N_{i i}+N_{j j}$ numbers observed of heterozygous and homozygous genotypes, respectively.

a includes all heterozygous trees at the given locus.

b excludes the trees with segregation distortion at that locus. (**) $P<0.010$; (*) $P<0.050$.

However, there was segregation deviation for the two last progenies $\left(B_{1} B_{4}\right.$ and $\left.B_{2} B_{4}\right)$ (Table 4$)$. The progeny of heterozygous mother tree $\left(B_{1} B_{4}\right)$ revealed an excess of genotype $N_{i k}\left(15\right.$ plants $B_{1} B_{2}$ and three $B_{1} B_{3}$, among 30 plants). The progeny T54 $\left(B_{2} B_{4}\right)$ showed an excess of $B_{2}$ allele. From 30 analyzed genotypes, 12 were homozygous $\left(B_{2} B_{2}\right)$ and 16 heterozygous $\left(B_{1} B_{2}\right)$ (see Table 5). The segregation distortion for both genotypes was allele-dependent and in this case disfavoring allele $B_{4}$. The more frequent allele at $P G I-B$ locus was $B_{2}$, followed by $B_{1}$. According to Sousa (2000), segregation distortion can also be attributed to selective advantage from the most frequent allele at locus.

6-PGDH-A showed significant (1\% level) segregation deviation (Table 4) as consequence of heterozygous excess. Eight samples showed segregation deviations, where two of them were statistically significant at $0.1 \%$ level, one at $1 \%$ level and five at 5\% level (Table 5). However, the data were adjusted to expected ratio when the progenies with deviation were excluded. The observed homozygotes excess for many trees, in particular in relation to $A_{2} A_{2}$ type, suggested a null allele segregating at this locus. The allele segregation for $B_{1}$ and $B_{2}$, from $6-P G D H-B$ was regular for just one analyzed progeny (Table 4). Segregation distortion has been reported by many authors such as Cheliak et al. (1984); Strauss and Conkle (1986); Sousa et al. (2002).
G-6PDH-A locus showed segregation distortion for both tests: total $\left(\sum G_{\text {hypothesisl:1 }}\right)$ and pooled segregation 1:1 $\left(G_{1: 1 \text { pooled }}\right)$. Individual segregation deviation was detected for six progenies: two at $5 \%$ significance level and four at $1 \%$ significance level. When the progeny with deviation were excluded, the segregation ratio 1:1 was established (Table 5). Segregation deviation for some trees was consequence of homozygous excess; however, it was not allele-dependent. The $A_{l}$ allele was favored in five progenies while $A_{2}$ only in one progeny (Table 5). The reason for this unbalanced value could be attributed to a null allele or sampling problem for this system. Cheliak and Pitel (1985) described a null allele at 6-PGDH gene loci in Larix laricina.

In the present work, segregation distortion at some loci was observed for a few individual trees. When these trees were excluded, the segregation was according to expected, as observed in $G$ test realized ( $G$ total, $G$ pooled and $G$ heterogeneity). Therefore, the analyzed loci were genetically controlled and segregating according to mendelian ratio (1:1).

Many authors described the segregation distortion for a few species in individual trees: Ying and Morgenstern (1990) for Larix laricina; Murillo and Hattemer (1997) for Alnus acuminata; Finkeldey et al. (1998) for Pterocarpus indicus; Konnert et al. (2001) for Acer pseudoplanatus and Sousa et al. (2002) for Araucaria angustifolia. 
Table 5 - Trees of I. paraguariensis showing deviation of segregation from the expected 1:1 ratio, for different enzyme loci.

\begin{tabular}{|c|c|c|c|c|c|c|c|c|c|c|c|}
\hline \multirow{2}{*}{$\begin{array}{l}\text { Enzyme } \\
\text { loci/Tree }\end{array}$} & \multirow{2}{*}{$\begin{array}{l}\text { Maternal } \\
\text { genotype }\end{array}$} & \multirow{2}{*}{$\begin{array}{c}\text { Sample } \\
\text { size }\end{array}$} & \multicolumn{5}{|c|}{ Observed segregation } & \multicolumn{2}{|c|}{$\chi^{2}(\mathrm{~A})$} & \multicolumn{2}{|c|}{$\chi^{2}(\mathrm{~B})$} \\
\hline & & & $N_{i i}$ & $N_{j j}$ & $N_{i j}$ & $N_{i k}$ & $N_{j k}$ & \multicolumn{2}{|c|}{$N_{i i}+N_{j j}=N_{i j}$} & \multicolumn{2}{|c|}{$N_{i k}=N_{j k}$} \\
\hline \multicolumn{12}{|l|}{$P G I-B$} \\
\hline C51 & $B_{1} B_{2}$ & 28 & & 1 & 1 & 1 & 25 & 0.00 & & 22.15 & $* * *$ \\
\hline T67 & $B_{1} B_{4}$ & 30 & 2 & 1 & 2 & 18 & 7 & 0.20 & & 4.84 & $*$ \\
\hline T54 & $B_{2} B_{4}$ & 29 & 12 & 0 & 0 & 17 & 0 & 12.00 & $* * *$ & 17.00 & $* * *$ \\
\hline \multicolumn{12}{|l|}{ 6-PGDH-A } \\
\hline S36 & $A_{1} A_{2}$ & 27 & 4 & 15 & 8 & - & - & 4.48 & $*$ & --- & \\
\hline CM39 & $A_{1} A_{2}$ & 23 & 3 & 19 & 1 & - & - & 19.17 & $* * *$ & --- & \\
\hline CM44 & $A_{1} A_{2}$ & 27 & 4 & 16 & 7 & - & - & 6.26 & $*$ & --- & \\
\hline C51 & $A_{1} A_{2}$ & 25 & 0 & 21 & 4 & - & - & 11.56 & $* * *$ & --- & \\
\hline T52 & $A_{1} A_{2}$ & 21 & 3 & 12 & 6 & - & - & 3.86 & $*$ & --- & \\
\hline T67 & $A_{1} A_{2}$ & 26 & 6 & 13 & 7 & - & - & 5.54 & $*$ & --- & \\
\hline $\mathrm{T} 75$ & $A_{1} A_{2}$ & 28 & 7 & 15 & 6 & - & - & 9.14 & $* *$ & --- & \\
\hline $\mathrm{T} 78$ & $A_{1} A_{2}$ & 22 & 4 & 12 & 6 & - & - & 4.72 & $*$ & --- & \\
\hline \multicolumn{12}{|l|}{$G-6 P D H-A$} \\
\hline CM34 & $A_{1} A_{2}$ & 30 & 19 & 4 & 7 & - & - & 9.63 & $* *$ & --- & \\
\hline S36 & $A_{1} A_{2}$ & 30 & 20 & 2 & 8 & - & - & 7.50 & $* *$ & --- & \\
\hline $\mathrm{C} 42$ & $A_{1} A_{2}$ & 29 & 7 & 13 & 9 & - & - & 4.97 & $*$ & --- & \\
\hline T66 & $A_{1} A_{2}$ & 30 & 14 & 7 & 9 & - & - & 5.63 & $*$ & --- & \\
\hline $\mathrm{T} 75$ & $A_{1} A_{2}$ & 28 & 11 & 10 & 7 & - & - & 8.04 & $* *$ & --- & \\
\hline $\mathrm{T} 80$ & $A_{1} A_{2}$ & 30 & 18 & 4 & 8 & & & 7.50 & $* *$ & --- & \\
\hline
\end{tabular}

\section{Linkage analysis}

Linkage disequilibrium was not performed for all the combinations in the five observed loci, since only few mother trees were heterozygous for many loci simultaneously. From ten possible combination pairs, only six were analyzed in relation to segregation independence of loci (Table 6).

Only three trees showed significant deviation from independent segregation hypothesis: CM39 (GOT$A: 6-P G D H-A)$, T52 (GOT-A:PGI-B) and C66 (PGI-B:G-6PDH-A). Although these loci seemed physically linked, the low value of linkage disequilibrium of Burrows $\left(\hat{\Delta}_{i j}\right)$ showed a weak linkage, considering the value range observed (0.25 a 0.25$)$. The more expressive measure of linkage disequilibrium $\left(\hat{\Delta}_{i j}\right)$, statistically significant at 5\% level, was observed for tree T66 between the loci PGI-B:G-6PDH-A (0.131) (Table $6)$.

The disequilibrium was significant at $5 \%$ level, just for one single tree in two loci combinations:
GOT-A:6-PGDH-A and PGI-B:G-6PDH-A (see Table 6). These results suggested that the observed disequilibrium was not a consequence of physical linkage between loci, but it was due to gametic disequilibrium as result of selection. If the disequilibrium resulted from physical linkage, all the analyzed trees should show absence of independent segregation between alleles and loci. Linkage disequilibrium was identified throughout chi-square test at $1 \%$ level only for the combination GOT-A:PGI-B. However, the observed value was based in one progeny only. To be sure about the strong dependency relationships between alleles, other studies involving more progenies would be necessary. Linkage disequilibrium between loci GOT-A:PGI-B was observed in Pinus taeda by Adams and Joly (1980). However, the authors could not attest if these loci were in the same chromosome. Linkage disequilibrium for GOT-A:6-PGDH-A and PGI$B: G-6 P D H-A$ combination has not yet been described for tree species. 
Table 6 - Burrows values for gametic disequilibrium $\left(\hat{\Delta}_{i j}\right)$ and chi-square test $\left(\chi^{2}\right)$ for independent segregation hypothesis for different isozyme loci pairs of I. paraguariensis

\begin{tabular}{|c|c|c|c|}
\hline \multirow{2}{*}{$\frac{\text { Locus combination/Trees }}{6-P G D H-A: G-6 P D H-A}$} & \multirow[t]{2}{*}{$\hat{\Delta}_{i j}$} & \multicolumn{2}{|c|}{$x^{2}$} \\
\hline & & & \\
\hline S36 & 0.009 & 0.04 & \\
\hline CM39 & -0.082 & 2.68 & \\
\hline T67 & -0.035 & 0.34 & \\
\hline T75 & 0.033 & 0.21 & \\
\hline \multicolumn{4}{|l|}{ GOT-A:6-PGDH-A } \\
\hline CM39 & -0.058 & 4.39 & $*$ \\
\hline T52 & 0.017 & 0.18 & \\
\hline \multicolumn{4}{|l|}{$P G I-B: 6-P G D H-A$} \\
\hline S36 & 0.018 & 0.21 & \\
\hline C51 & -0.006 & 0.20 & \\
\hline T52 & 0.024 & 0.68 & \\
\hline T78 & 0.056 & 1.15 & \\
\hline \multicolumn{4}{|l|}{ GOT-A:G-6PDH-A } \\
\hline CM39 & -0.064 & 3.63 & \\
\hline \multicolumn{4}{|l|}{ GOT-A:PGI-B } \\
\hline T52 & 0.057 & 305.09 & **** \\
\hline \multicolumn{4}{|l|}{$P G I-B: G-6 P D H-A$} \\
\hline S36 & -0.043 & 2.06 & \\
\hline C42 & 0.042 & 0.57 & \\
\hline T66 & 0.131 & 5.88 & $*$ \\
\hline $\mathrm{T} 78$ & -0.030 & 0.57 & \\
\hline
\end{tabular}

(*) $\mathrm{P}<0.050 ;(* * *) \mathrm{P}<0.001$.

Exclusion of a locus from each linkage pair allows breaking the association between them and can be used to study breeding system and paternity analysis. Linkage disequilibrium measure of Burrows indicated that the linkage was probably weak and, therefore, the multilocus parameters must not be affected. Linkage disequilibrium was not observed for combination between loci; therefore, the alleles from different loci were not linked and segregate randomly.

Inheritance and relationships studies indicated the loci GOT, PGI, 6-PGDH and G-6PDH could be useful as genetic marker in population genetics of Ilex paraguariensis species.

\section{ACKNOWLEDGEMENT}

The authors thank the National Center for Forestry Research of Brazilian Agriculture Research Corporation - EMBRAPA for sponsoring this project and the CNPq "Conselho Nacional de Desenvolvimento Científico e Tecnológico" who granted a scholarship to the first author.

\section{RESUMO}

Dezoito sistemas enzimáticos foram analisados em Ilex paraguariensis, utilizando eletroforese em gel de amido. Sete dos 12 sistemas que apresentaram atividade enzimática revelaram um ou mais locos polimórficos (PGI, GOT, MR, G-6PDH, MDH, $\mathrm{NDH}$ e 6-PGDH). Entretanto, as análises de segregação e desequilíbrio de ligação foram realizadas somente nos sistemas PGI, GOT, G6PDH e 6-PGDH. A segregação destes locos foi regular, exceto para algumas árvores, que apresentaram distorções de segregação. Foram detectados indícios de desequilíbrio de ligação entre alguns locos, mas que não devem influenciar as estimativas multilocos.

\section{REFERENCES}

Adams, W. T. and Joly, R. J. (1980), Linkage relationships among twelve allozyme loci in loblolly pine. J. Hered., 71, 199-202.

Bergmann, F. and Hattemer, H. H. (1998), Isozymes in forest genetics research. In- Forest Genetics and Tree 
Breeding, eds. Mandal, A. K. and Gibson, G. L. CBS Publishers and Distributors, New Dehli , pp 227-238.

Cheliak, W. M.; Morgan, K.; Dancik, B. P.; Strobeck, C. and Yeh, F. C. (1984), Segregation of allozymes in megagametophytes of viable seed from a natural population of jack pine, Pinus banksiana Lamb. Theor. Appl. Genet. 69, 145-151.

Cheliak, W. M. and Pitel, J. A. (1985), Inheritance and linkage of allozymes in Larix laricina. Silvae Genetica, 34, 142-148.

Fallour, D.; Fady, B. and Lefevre, F. (1997), Study on isozyme variation in Pinus pinea L.: evidence for low polymorphism. Silvae Genetica, 46, 201-207.

Finkeldey, R. (1998), An Introduction to Tropical Forest Genetics. Lecture Notes. Georg-August University Göttingen, Institute of Forest Genetics and Forest Tree Breeding, $241 \mathrm{pp}$.

Finkeldey, R., Guzman, N. de and Changtragoon, S. (1998), Inheritance of isozyme phenotypes in Pterocarpus indicus Willd. Forest Genetics, 3, 165170.

Furnier, G. R.; Knowles, P. Aleksiuk, M. A. and Dancik, B. P. (1986), Inheritance and linkage of allozymes in seed tissue of white bark pine. Can. J. Genet. Cytol., 28, 601-604.

Gillet, E. and Hattemer, H. H. (1989), Genetic analysis of isoenzyme phenotypes using single tree progenies. Heredity, 63, 135-141.

Glaubitz, J. C. and Moran, G. F. (2000): Genetic tools: the use of biochemical and molecular markers. InForest Conservation Genetics: Principles and Practice, eds. Young, A., Boshier, D. and Boyle, T. CABI Publishing, New York, pp. 39-59.

Konnert, M.; Ruertz, W. and Fromm, M. (2001), Genetic variation in Acer pseudoplatanus L. I. Inheritance of isozyme variants. Forest Genetics, 8, 25-37.

Lewis, P.O. and Zaykin, D. (1999), Genetic Data Analysis: versão 1.1 for Windows 95/NT. http://lewis.eeb.uconn.edu/lewishome/.

Maccari Junior, A. (2000), Produtos alternativos e desenvolvimento da tecnologia industrial na cadeia produtiva da erva-mate. Curitiba, Câmara Setorial de Cadeia Produtiva de Erva-mate (Série PDACT, 1) $160 \mathrm{pp}$.
Murillo, O. and Hattemer, H. H. (1997), Inheritance of isozyme variants in Alnus acuminata ssp. arguta (Schlectendal) Furlow. Silvae Genética, 46, 51-55.

Oliveira, Y. M. M. and Rotta, E. (1985), Área de distribuição natural de erva-mate (Ilex paraguariensis St. Hil.). In-Seminário sobre atualidades e perspectivas florestais, 10: Silvicultura da erva-mate (Ilex paraguariensis St. Hil.). Anais. Curitiba, EMBRAPA-CNPF, pp. 17-36.

Sebbenn, A. M. (2004), Herança e desequilíbrio gamético em algumas isoenzimas polimórficas em Genipa americana L. Revista do Instituto Florestal, 16, 65-72.

Sokal, R. R. and Rohlf, F. J. (1981), Biometry. The Principle and Practice of Statistics in Biological Research. 2 ed. Freeman and Co San Francisco, USA, 859 pp.

Sousa, V. A. (2000), Population genetic studies in Araucaria angustifolia (Bert.) O. Ktze. PhD Thesis, Faculty of Forest Sciences and Forest Ecology. Georg August University of Göttingen. Cuvillier Verlag Göttingen 160 pp.

Sousa, V. A.; Hattemer, H. H. and Robinson, I. P. (2002), Inheritance and linkage relationships of isozyme variants of Araucaria angustifolia (Bert.) O. Ktze. Silvae Genetica, 51, 191-196.

Strauss, S. H. and Conkle, M. T. (1986), Segregation, linkage and diversity of allozymes in knobcone pine. Theor. Appl. Genet., 72, 483-493.

Weir, B. S. (1979), Inferences about linkage disequilibrium. Biometrics, 35, 235-354.

Wendt, S. N. (2005): Genética de populações em Ilex paraguariensis St. Hil. $\mathrm{PhD}$ Thesis, Curso em Processos Biotecnológicos, Universidade Federal do Paraná, Curitiba, Brasil, 165 pp.

Willians, C. G. and Savolainen, O. (1996), Inbreeding depression in conifers: implications for breeding strategy. Forest Science, 42, 102-117.

Ying, L. and Morgenstern, E. K. (1990), Inheritance and linkage relationships of some isozymes of Larix laricina in New Brunswick, Canada. Silvae Genetica, 39, 245-251.

Received: June 08, 2007; Revised: November 20, 2008; Accepted: March 27, 2009. 